\title{
Biomarkers for Evaluation of Prostate Cancer Prognosis
}

\author{
Maryam Esfahani ${ }^{1}$, Negar Ataei ${ }^{1}$, Mojtaba Panjehpour ${ }^{2 *}$
}

\begin{abstract}
Prostate cancer, with a lifetime prevalence of one in six men, is the second cause of malignancy-related death and the most prevalent cancer in men in many countries. Nowadays, prostate cancer diagnosis is often based on the use of biomarkers, especially prostate-specific antigen (PSA) which can result in enhanced detection at earlier stage and decreasing in the number of metastatic patients. However, because of the low specificity of PSA, unnecessary biopsies and mistaken diagnoses frequently occur. Prostate cancer has various features so prognosis following diagnosis is greatly variable. There is a requirement for new prognostic biomarkers, particularly to differentiate between inactive and aggressive forms of disease, to improve clinical management of prostate cancer. Research continues into finding additional markers that may allow this goal to be attained. We here selected a group of candidate biomarkers including PSA, PSA velocity, percentage free PSA, TGFß1, AMACR, chromogranin A, IL-6, IGFBPs, PSCA, biomarkers related to cell cycle regulation, apoptosis, PTEN, androgen receptor, cellular adhesion and angiogenesis, and also prognostic biomarkers with Genomic tests for discussion. This provides an outline of biomarkers that are presently of prognostic interest in prostate cancer investigation.
\end{abstract}

Keywords: Biomarkers - prostate cancer - PSA - prediction of prognosis

Asian Pac J Cancer Prev, 16 (7), 2601-2611

\section{Introduction}

One of the most important health problems in men is prostate cancer (Howlader et al., 2011). Predominantly it is an older men disease as the rate of prostate cancer increases significantly after of 40 year and about two-thirds of all prostate cancers occur in men 65 and older (Howlader et al., 2011; Timothy Wilt, 2013). It is estimated 307,000 men died due to prostate cancer in 2012 in worldwide (UK, 2012). Incidence and mortality of prostate cancer in most native Asian population progressively raised, but are approximately one-third lower in corresponding Asian-American cohorts, which are themselves less than the rates in other corresponding American cohorts (Ito, 2014). Generally, incidence rate in more developed regions is obviously greater than less developed regions (Globocan, 2012).

Genetic and environmental factors, especially a western diet could partially describe these differences. Of course lower exposure to prostate-specific antigen (PSA) screening program in Asian people might be an important factor (Ito, 2014).This disease has various features contain slow-growing tumor with no clinical consequence, or develops rapidly which lead to aggressively metastatic and lethal outcome (Cary and Cooperberg, 2013). Prostate cancer, with a lifetime prevalence of one in six men, is the second cause of death and the most prevalent cancer in men (Panjehpour et al., 2012). This cancer has an important role in morbidity and mortality of men.
The symptoms of prostate cancer are infrequent at the time of diagnosis, because of local growth of the tumor, symptoms of urinary obstruction like decreased urinary stream, urgency, hesitancy, nocturia and incomplete bladder emptying may occur. These nonspecific symptoms are more indicative for benign prostatic hyperplasia (Lawrence, 2011).

Prostate cancer risk factors may be divided two categories: exogenous and endogenous, albeit some factors are not solely one or the other such as race, aging, oxidative stress. Endogenous risk factors are included aging and oxidative stress, family history, and race (the risk of prostate cancer is higher in AfricanAmerican races than the other races) and hormones as altered androgen metabolisms may have significant role in prostate cancer. Endogenous and exogenous factors may have effect on hormonal levels (Bostwick et al., 2004). Some of exogenous risk factors are including rich fat diets particularly poly unsaturated fat, vitamin deficiency especially vitamin D and E (Garg et al., 2014), beside fruits and vegetable intake may decrease prostate cancer risk (Askari et al., 2014), environmental agents such as endocrine disrupting chemicals-EDCs (Euling and Kimmel, 2001), cadmium, occupational factors (Doolan et al., 2014), like farming or working in the rubber industry. Other factors included smoking, energy intake, vasectomy, physical activity and anthropometry (Bostwick et al., 2004).

Currently screening has an important role in prostate

${ }^{1}$ Department of Clinical Biochemistry, ${ }^{2}$ Department. of Clinical Biochemistry \& Bioinformatics Research Center, School of Pharmacy and Pharmaceutical Sciences, Isfahan University of Medical Sciences, Isfahan, Iran *For correspondence: e-mail 
cancer diagnosis and PSA test is the most greatly noninvasive screening tool which causes enhanced detection at earlier stage and decreasing in the number of metastatic patients but because of low specificity of PSA, unnecessary biopsies and error diagnose is performed (Euling and Kimmel, 2001; Cary and Cooperberg, 2013).

As noted above prostate cancer has various features, so the prognosis following diagnosis is greatly variable (Bickers and Aukim-Hastie, 2009). Some patients have inactive form of disease with no important effect on mortality for 15 years, on the other hands some patients have aggressive form of the disease as metastasis may occur during 2 years (Siddiqui et al., 2004), metastasis has important role in cancer mortality (Bickers and Aukim-Hastie, 2009). There is requirement for new and high sensitive prognostic biomarkers to improve clinical management of prostate cancer particularly can differentiate between inactive and aggressive form of disease. The researches continue for finding additional markers that provide these goals (Ramirez et al., 2008). For new therapeutics, it is necessitate developing more reliable biomarkers. Currently, many prostate cancer biomarkers have been identified and are investigating (Bensalah et al., 2007).This short review mainly depicts studies that have researched new biomarkers and introduced new viewpoints on prognostic biomarkers of prostate cancer and illustrating their benefits and limitations (Table 1). This paper is neither intended to be a comprehensive depiction of the individual biomarkers nor including list of all available biomarkers because the list of biomarkers is in evolvement and finding is beyond that described here.

\section{Characteristics of Biomarkers}

Biomarker (biological marker) is a molecule that can be measured and evaluated as an indicator of normal biological, pathological processes or pharmacological response to a therapeutic intervention (Ilyin et al., 2004). An ideal biomarker has multiple characteristics:

i) Disease-specific; ii) Slightly invasive; iii) Costeffective; $i v$ ) Reproducible assay with sufficient sensitivity and specificity; v) Perfectly with correlation to disease outcome(Lin, 2009).

Cancer biomarkers are generally grouped into three categories: prognostic, predictive, pharmacodynamic. Prognostic biomarkers predict the natural course of cancer and to recognize tumor's outcome. Predictive biomarkers assess possible advantage of a special treatment. Therapeutic impacts of a drug on a tumor are evaluated by pharmacodynamic biomarkers, these biomarkers perhaps determine the suitable dosage of a novel anticancer drug in the early steps of clinical progression (Madu Co, 2010).

\section{Prostate-Specific Antigen (PSA)}

PSA is a kallekrein-like serine protease secreted by the epithelial cells of prostate and encoded by an androgen-responsive gene (19q 13.3-13.4) (Riegman et al., 1989). The major role of PSA is liquefying of human semen by its proteolytic function (Lin, 2009; Madu Co,
2010). Serum PSA level is age and race dependent, Age specific range of PSA in different races indicated in table-2 (Zorn KC, 2014). It is reported that if the upper limit of normal PSA increases in men aged 60-69 years $(4.5 \mathrm{ng} /$ $\mathrm{ml}$ ), an important loss in sensitivity occurs (Bassler $\mathrm{Tj}$ $\mathrm{Jr}$ and O'Dowd Gj, 1998). Routinely, PSA is the only biomarker that is used for diagnosis and prognosis of prostate cancer(Rittenhouse et al., 1998).The extensive use of the PSA test increased detection of disease at earlier stages(Ilyin et al., 2004), which caused a decrease in number of patients in metastatic state(Shariat et al., 2008a). Because high levels of PSA are found in more progressive stages and more unfavorable result, this biomarker has been used as a staging and prognostic tool(Shariat and Kevin, 2004).

In spite of this significant role, PSA is organ-specific but not cancer specific. The serum PSA level increases in benign prostatic hyperplasia (BPH: increase in size of prostate secondary to a noncancerous proliferation of prostate gland cells) (Charrier et al., 2001), prostatitis (inflammation of prostate) (Tricoli et al., 2004), following interventions like biopsy (Yuan et al., 1992), also in older age, ejaculation(16) and use of specific drugs such as male hormones. On the other hand, numerous factors may cause decrease in PSA level such as 5- $\alpha$ reductase inhibitors, herbal mixtures, obesity, aspirin, statins, thiazide diuretics (Society, 2013). Hence false positives are a major difficulty for PSA test. This unspecificity has led to the over diagnosis of inactive disease (Etzioni et al., 2002), but upper limit $4 \mathrm{ng} / \mathrm{ml}$ eliminates the majority of prostate cancers (Shariat et al., 2008a). The studies indicated that cut off $4.1 \mathrm{ng} / \mathrm{ml}$ can distinguish only $20.5 \%$ of prostate cancer cases (Thompson et al., 2005). Recent data indicated that considerable number of men had prostate cancer within normal range of PSA and importantly many of these patients were found to be high grade (Lin, 2009). The association between total PSA and prostate cancer has impaired over the last 20 years (Stamey et al., 2002; Shariat et al., 2006). In order to increase PSA diagnostic specificity and prognostic ability, several parameters of PSA have been used.

\section{PSA Velocity (PSAV)}

PSAV, sequential evaluation of PSA levels over time (Sardana et al., 2008) or ratio of increase of PSA before diagnosis, has been found to be an independent predictor of return of disease after radical prostatectomy (Patel et al., 2005). The studies revealed that BPH patients had a linear increase in PSA level over time, while prostate cancer patients had a first increase following by an exponential rise which occurred 5years before cancer detection (Shariat et al., 2008a). Some studies indicated that PSA velocity $>2 \mathrm{ng} / \mathrm{ml}$ per year pre diagnosis, associated with a shorter disease-free survival time in spite of radical prostatectomy (D'Amico et al., 2004). The specificity of PSAV is high but its sensitivity is so low that couldn't inescapable prostate biopsy in a patient with increased PSA level, another limitation is as a result of biological and analytical variation (such as PSA stability, PSA measuring differences) that cause day-to-day variation in PSA level 
and eventually imprecision of PSA velocity (Nixon et al., 1997). It is recommended that PSAV may be useful in patients with normal serum PSA level at the beginning of screening, but it is less beneficial in deciding whether patients with a serum PSA level of $4-10 \mathrm{ng} / \mathrm{ml}$ must be biopsied (Shariat et al., 2008a). The researchers defined "PSAV risk count", a new way to assess PSA dynamic which computed by counting the number of times that PSAV goes beyond a particular threshold value (Carter $\mathrm{Hb}, 2007)$. The studies indicated that PSAV risk count may decrease unnecessary prostate biopsies and diagnoses low-risk prostate cancer (Loeb et al., 2012).

\section{Percentage Free PSA}

Serum PSA is in several molecular forms that classified into two categories, free PSA (unbound) and complexes PSA (bound to protease inhibitor such as $\alpha 1$-antichymotrypsin, $\alpha 1$-antitrypsin, $\alpha 2$ macroglobulin) (Shahrokh F Shariat and Kevin, 2004). Free PSA comprises $5-45 \%$ of total PSA, percentage of free PSA (\%Free PSA) calculated by free PSA/total PSA $* 100$ (Shariat et al., 2008a). The use of \%Free PSA has been certified as an appendix to total PSA testing in men with a serum total PSA level of $4-10 \mathrm{ng} / \mathrm{ml}$ (Shariat et al., 2008a). The researchers suggested free PSA as a latestage predictor of prostate cancer (Finne et al., 2008). It seems that \%PSA is inversely associated with risk of finding prostate cancer in biopsy (Bickers B, 2009). The association of free/total PSA ratio in men with PSA levels of $2.1-10.0 \mathrm{ng} / \mathrm{ml}$ and probability of prostate cancer indicated in table-3 (Kitagawa et al., 2014).It is indicated that \% free PSA is significantly low in aggressive disease conditions like Gleason score $\geq 7$, metastases, positive surgical margins (Catalona et al., 1998).It is noted that Gleason score is a prognosting grading system based absolutely on histological pattern on differentiation and organization of carcinoma cells, this score is identified as one of the most important predictors of disease outcome and changes from 2 to 10 (Buhmeid, 2006). It is found that using a \%free PSA cut-off value of $25 \%$,can detect prostate cancer with a $95 \%$ sensitivity and prevent $20 \%$ of unnecessary biopsies (Catalona et al., 1998). Some studies found that \%free PSA may be a better predictor of postoperative pathological outcome as compared to Gleason grade (Southwick et al., 1999), although the some studies don't confirm this opinion (Jung and et al., 2000; Graefen et al., 2002).

\section{Transforming Growth Factor $\beta 1$ (TGFß1)}

A prominent regulator of the normal and malignant prostate is TGF $\beta 1$. This multifunctional cytokine causes dys regulation of cell cycle, stimulates angiogenesis also increases proteases and extra cellular matrix (Wikstrom et al., 2001; Achyut and Yang, 2011). It is indicated association between high level of this cytokine in prostate cancer tissue and increased tumor grade, tumor stage (Shariat et al., 2004b), biochemical recurrence and patterns of invasion of disease such as extra capsular extension and seminal vesicle invasion (Shariat et al., 2004a; Shariat et
Biomarkers for Evaluation of Prostate Cancer Prognosis al., 2008b), although there are some studies indicating noassociation (Perry et al., 1997; Wolff et al., 1999).

\section{Alpha-methylacyl-CoA Racemase(AMACR)}

This enzyme involved in $\beta$-oxidation of branched chain fatty acids and the bile acid intermediates dihydroxycholestanoic acid and trihydroxycholestanoic acid. Particularly, it is involved in conversion of (2R) $\alpha$-methyl branched chain fatty acyl- CoA to their S-stereoisomers (Van Veldhoven et al., 1997; Ferdinandusse et al., 2000). AMACR strongly produced in prostate tissue (Sardana et al., 2008), and AMACR gene over expressed in prostate cancer (Jiang et al., 2004). Some researchers found that measurements of serum AMACR auto antibodies used as highly sensitive and specific diagnostic test (Sreekumar et al., 2004). Also AMACR may have a prognostic value, because reduction of this protein has been associated with increasing possibility of biochemical recurrence and unfavorable prognosis in prostate cancer (Bishoff et al., 2014). AMACR mRNA in serum and urine can be detected by reverse transcriptionPCR analysis (Al-Maghrebi et al., 2012).

\section{Chromogranin A}

ChromograninA ( $\mathrm{CgA})$, a member of the granin family of neuroendocrine secretory proteins, generated by the neuroendocrine cells in the prostate is a marker of neuroendocrine differentiation (Isshiki et al., 2002). Although serum level of $\mathrm{CgA}$ is not specific for prostate cancer, it is associated with tumor stage and grade (Bocan et al., 2011). It has potential to detect androgenindependent disease. There is high serum level of $\mathrm{CgA}$ in late -stage of disease and predict poor prognosis in androgen-independent prostate cancer following endocrine therapy (Berruti et al., 2001; Khan and Ather, 2011). Also studies revealed that serum $\mathrm{CgA}$ combined with serum PSA, may efficiently prophecy poor prognosis following endocrine therapy(Isshiki et al., 2002). With future clinical evaluation, it is appeared that $\mathrm{CgA}$ may be used as a prognostic/treatment marker for prostate cancer.

\section{Interleukin-6(IL-6) and the other Interleukins}

IL-6, a $30 \mathrm{KD}$ glycoprotein, has role in regulation of immune system, hematopoiesis, acute phase responses, cell growth and differentiation (Nakashima et al., 2000). IL-6 involved in regulation of VEGF expression and neuroendocrine differentiation in prostate (Culig et al., 2005). It is exhibited that IL-6 acts as a paracrine and autocrine growth factor for prostate cancer cells (Shariat et al., 2001). Several studies reported that high level of IL-6 and its receptor was associated with aggressive state of disease such as higher Gleason score, advanced stage, progression of metastasis, and androgen-independent prostate cancer (Kattan et al., 2003; Shariat et al., 2004a), as well as few studies indicated reduction of survival (Michalaki et al., 2004; George et al., 2005). It should be noted that addition of pretreatment TGF- $\beta$ and IL-6 receptor to the nomogram increases the prediction 
of biochemical recurrence (Shariat et al., 2008a). IL$1 \beta$, TNF- $\alpha$ and Interferon $\beta$ (IFN $\beta$ ) are important inflammatory-related molecules which may impact on biological features of prostatic tumors and outcome of patients. The studies suggested that prostatic expression of these molecules and their signaling proteins involved in prediction of clinical outcome (Rodriguez-Berriguete et al., 2013; Eiro et al., 2014).

\section{Insulin-like Growth Factor and Insulin-like Growth Factor Binding Proteins (IGFBPs)}

IGF-I, IGF-II, two receptors (IGFR1, IGFR2) and binding proteins (IGFBP1-6) constitute Insulin-like growth factor systems. IGF-I, a strong stimulator of normal and neoplastic cell growth, has anti-apoptotic effects on prostate epithelial cells (Djavan et al., 2001; khodadadi E, 2013). In vivo and In vitro experiments revealed that proliferation of androgen-dependent and androgenindependent prostate cancer cell lines are promoted by IGF-1 (Chan et al., 2002)(80). The main binding protein for IGF-I is IGF binding protein-3(IGFBP-3) that effects on bioavailability of IGF-I (khodadadi E, 2013). IGFBP-3 can reduce growth stimulating effects of IGF-I and suppress cell proliferation in several cell systems including prostate cancer (Safarinejad et al., 2011). This protein stimulates apoptosis via activation of caspases through a death receptor mechanism in MC-7 human breast cancer cells (Kim et al., 2004). IGFBP-3 gene involved in cellular senescence and its expression is down regulated in human prostate cell lines (Schwarze et al., 2002). Low IGBP-3 level is correlated with increased risk of aggressive and metastatic prostate cancer (Mehta et al., 2011). The circulating level of IGF-I and IGFBP-3 may be effect on invasion and metastasis of low grade tumors (Chan et al., 2002).

High plasma level of IGFBP-2, major IGF binding protein in prostate epithelial cells, associated with prostate cancer. Also there is inverse correlation between IGFBP-2 level and aggressive features of higher Gleason score, extra prostatic extension and seminal vesicle involvement (Shariat et al., 2002). It has been suggested that preoperative assessment of serum levels ofIGFBP-2 and IGFBP-3 possibly useful in prostate cancer prognosis because of their association with the risk of disease progression and facility of measurement in the blood (Shariat et al., 2002). Of course, some studies suggested that serum level of IGF-1, IGFBP-2 and IGFBP-3 have no prognostic value in progression of prostate cancer ( $\mathrm{Yu}$ et al., 2001).

\section{Prostate-Stem Cell Antigen (PSCA)}

PSCA, a glycosylphosphatidyl inositol-anchored cell surface, mainly expressed in prostate and may be involved in stem cell functions like proliferation or signal transduction (Tricoli et al., 2004), also in tumor genesis, cell adhesion and prevention of apoptosis(Reiter et al., 1998), but exact role of PSCA in prostate is not clear (Tricoli et al., 2004). PSCA is co-amplified with c-myc, a tumor progression factor and oncogene (Reiter et al.,
2000). Some studies showed PSCA over expression in great number of prostate cancers (Han et al., 2004; Zhigang and Wenlv, 2004), which is associated with higher Gleason grade and more progressed tumor stage, higher degree of metastasis (Hara et al., 2002). PSCA expression preserved in androgen-independent prostate cancer (Zhigang and Wenlv, 2004). The recently studies suggested that under-expression of PSCA is correlated with metastatic progression of prostate cancer and its over expression associated with early stage of disease (Larkin et al., 2012). However immunohistochemical method used in analysis of PSCA in prostate tissue, RT-PCR method can be detected PSCA RNA in peripheral blood (Hara et al., 2002).Perhaps with further experiments, its potential as a blood-based biomarker more be recognized and used for prostate cancer prognosis.

\section{Other Biomarkers}

There are the other candidate biomarkers that associated with prognosis involved in different cellular process such as: cell cycle regulation and proliferation, cell death, signal transduction, cell adhesion and angiogenesis (Lopergolo and Zaffaroni, 2009).

\section{Biomarker related to cell cycle regulation}

Dysregulationof cellcycle, especially transition of G1to S phase, occurs in all human cancers (Lopergolo and Zaffaroni, 2009). Cyclin/Cyclin -Dependent Kinase (CDK) complexes control progression of G1/S phase.

There are various endogenous CDK inhibitors with different but overlapping specificities, comprising P27kip1, P27 WAF1, and P16INK4, some cohort studies showed that decreased expression of P27 may be an independent adverse prognostic factor in localized prostate cancer (PSA recurrence) (Kuczyk et al., 2001; Freedland et al., 2003).

It is demonstrated that P21 over expression, before and after hormone therapy, associated with advanced prostate cancer (Buhmeid A, 2006). This over expression was independently linked with high biochemical failure in patients treated with neoadjuvant androgen deprivation before salvage radiotherapy (Rigaud et al., 2004).

$\mathrm{Ki}-67$, a DNA binding protein, is present in all phases of cell cycle except resting cells.Several studies indicated that high Ki-67 (proliferation index) associated with high biochemical failure in localized prostate cancer (Rubio et al., 2005; Laitinen et al., 2008), also associated with poor outcomelike high rate of distant metastasis and reduction of disease-specific survival (in hormone therapy or radiotherapy in the context of the RTOG-8610 and RTOG9202 clinical trials (Li et al., 2004a; Pollack et al., 2004).

\section{Biomarkers related to apoptosis}

There are two main pathways of apoptosis: extrinsic and intrinsic pathway. Intrinsic or mitochondrial pathway is activated by pro-apoptotic signals and lead to the release of Cytochrome $\mathrm{c}$ from mitochondria and eventually activation of caspase-9. P53 and BCL-2 protein family are the main regulators of this pathway. Mutations of P53 have been associated with prostate cancer (Quinn Di, 2005). 
Abnormal P53 protein may be as a predictor of disease recurrence following radical prostatectomy. It is indicated associations between this protein and aggressive features of disease like metastasis and reduction of survival. Over expression of P53 in preoperative biopsies of patients with localized prostate cancer (treated with radical prostatectomy) was associated with increased rate of biochemical failure (Oxley Jd, 2002). In addition to, cohort studies depicted that over expression of P53 in patients who underwent radiotherapy with or without hormone therapy in the context of RTOG-8610 trials, predicts poor outcome of high rate of distant metastasis, decreased overall survival (Grignon et al., 1997). Proliferation blockage and apoptosis induction of prostate cancer cells are considered as new treatment for this cancer (Aghaei et al., 2011).

\section{PTEN (phosphatase and tensin homolog)}

PTEN is an important tumor suppressor gene. The PTEN signaling pathway has major role in the survival and proliferation of prostate cancer cells, also involves in regulation of prostate adenocarcinoma angiogenesis (Fang et al., 2007). PTEN deletion is indicated in prostate cancer (Yoshimoto et al., 2007). Some studies reported that decrease or loss of PTEN expression were correlated with more advance of disease including higher Gleason grade, greater tumor, progressive pathological stage and extra prostatic extension (Koksal et al., 2004; Yoshimoto et al., 2007). Also researches indicated that PTEN deletions and decreased its expression associated with biochemical recurrence (Chaux et al., 2012) and metastasis (Lotan et al., 2011). It is suggested that PTEN loss is correlated with suppression of androgen receptor signaling, in fact represses androgen responsive genes (Mulholland et al., 2011). However other studies indicated that PTEN expression did not prophesy prostate cancer outcome when assayed separately and it did when combined with other biomarkers (Bedolla et al., 2007; Li et al., 2011). So, it is appeared that further research is needed.

\section{Androgen receptor}

The Androgen receptor (AR), a nuclear transcription factor, binds male sex steroids and involves in their biological effects in target cells. AR activated transcription of androgen-dependent genes, these receptors have an important function in prostate cancer (Donovan et al., 2008). One of the important therapeutic options in advanced prostate cancer is deprivation of androgens or peripheral obstruction of androgen action, but many prostate cancers become hormone refractory, develop more and eventually lead to deadly outcome (Buhmeid A, 2006). Several molecular mechanisms involve in development of hormone refractory, and androgen receptors and their signaling pathway have significant role (Linja and Visakorpi, 2001). AR over expression associated with progression, recurrence, lymph node metastasis and/or hormone refractory in prostate cancer (Quinn Di, 2005). The higher AR mRNA was independently associated with increased biochemical failure (Rosner et al., 2007). It is suggested that accurate quantification of $\mathrm{AR}$ at the time of prostatectomy and biopsy lead to more suitable clinical
DOI:http://dx.doi.org/10.7314/APJCP.2015.16.7.2601

Biomarkers for Evaluation of Prostate Cancer Prognosis management (Donovan et al., 2008).

\section{Biomarker related to cellular adhesion}

Cell-cell adhesion has critical role in the maintenance of tissue structure and cohesion. Cell adhesion molecules have important role in cancer invasion and metastasis (Kuniyasu H, 2000). E-cadherin, a 120 KD transmembrane glycoprotein and a member of cadherin family, involved in cell-cell recognition and adhesion. Meta analysis studies indicated that some gene polymorphisms of E-cadherin are associated with increased risk of prostate cancer (Deng et al., 2014). Reduced expression of E-cadherin in prostate cancer samples was associated with poor prognosis and aggressive transformation (Chunthapong, 2004). It is noted that low level of E-cadherin is reported in localized prostate cancer, and metastatic prostate cancer showed high expression of E-cadherin (Rubin Ma, 2001). The reduction of E-cadherin and the elevation of $\mathrm{N}$-cadherin (the other classic cadherins) characterizes epithelial to mesenchymal transition (EMT) which defines as "N-cadherin switching", EMT is associated with biochemical failure and clinical recurrence in prostate cancer (Gravdal K and et al., 2007). It is demonstrated that $\mathrm{N}$-cadherin switching associated with advanced Gleason score. $\mathrm{N}$-cadherin possibly used as a biomarker of aggressive prostate cancer (Jaggi M, 2006), measurement of EMT markers may involve in precise prediction of biochemical outcome after prostatectomy (Behnsawy et al., 2013).

\section{Biomarker related to angiogenesis}

Growth and metastatic spreading of cancer is depended on neoangiogenesis. Adhesion molecules, nitric oxide, cyclooxygenases and VEGFs regulate blood vessel formation (Kollermann, 2001). VEGF, an important regulator of angiogenesis, play a major role in tumor angiogenesis (Hicklin and Ellis, 2005). There are at least four isoforms of VEGF with various functions and receptors affinities including A,B,C,D (Quinn Di, 2005). Higher expression of VEGF occurs in prostate cancer (Erkal et al., 2014), also VEGF receptor expression arises extensively in prostate carcinoma (Kollermann, 2001). The expression of VEGF-C and VEGFR-3 increased in prostate cancer, which have role in lymph angiogenesis and lymph node metastasis (Yang et al., 2006; Di et al., 2009). Higher VEGFR-3 expression predicts early tumor progression following radical prostatectomy ( $\mathrm{Li}$ et al., 2004b), also higher VEGF expression associates with recurrence and survival in localized prostate cancer (Halvorsen, 2008; Vergis et al., 2008).

Some of the biomarkers involved in prostate cancer prognosis are indicated in Table 1, with details as to characteristics and detection method.

\section{Prognostic Biomarkers with Genomic tests}

\section{Genomic classifier (GC) and Decipher}

Genomic classifier (GC) that is associated with aggressive prostate cancer is evaluated with decipher test. This novel genomic test used after prostatectomy and evaluated 22 RNA biomarkers expression associated with 
Table 1. Biomarkers Involved in Prostate Cancer Prognosis (after Getzenberg., 2006; Ramirez et al., 2008)

\begin{tabular}{|c|c|c|c|c|c|}
\hline Marker & Description & Function & Purpose & Method of detection & Advantage/ Dis advantage \\
\hline PSA & $\begin{array}{l}\text { A glyco- } \\
\text { protein and } \\
\text { a member } \\
\text { of the } \\
\text { kallikrein- } \\
\text { related pepti- } \\
\text { dase family } \\
\text { secreted by } \\
\text { the epithe- } \\
\text { lial cells of } \\
\text { the prostate } \\
\text { gland }\end{array}$ & $\begin{array}{l}\text { Serine protease } \\
\text { involved in the } \\
\text { liquefaction of } \\
\text { seminal fluids. }\end{array}$ & $\begin{array}{l}\text { Prog- } \\
\text { nosis/ Di- } \\
\text { agnosis }\end{array}$ & $\begin{array}{l}\text { Serum immunoas- } \\
\text { says used to measure } \\
\text { free PSA, com- } \\
\text { plexed PSA, and } \\
\text { total PSA. }\end{array}$ & $\begin{array}{l}\text { An organ specific biomarker, easy } \\
\text { measurement/ Lack of specificity and the } \\
\text { inability to distinguish between aggressive } \\
\text { and indolent cancers, poor accuracy }\end{array}$ \\
\hline $\begin{array}{l}\text { Chro- } \\
\text { mogranin } \\
\text { A }\end{array}$ & $\begin{array}{l}\text { Pro-hormone } \\
\text { peptide } \\
\text { released by } \\
\text { neuroendo- } \\
\text { crine cells. }\end{array}$ & $\begin{array}{l}\text { Unclear. It has } \\
\text { calcium-binding } \\
\text { properties }\end{array}$ & $\begin{array}{l}\text { Progno- } \\
\text { sis }\end{array}$ & $\begin{array}{l}\text { Immunoassay, im- } \\
\text { munoradiometric } \\
\text { assay, ELISA. }\end{array}$ & $\begin{array}{l}\text { Potential to detect androgen-independent } \\
\text { disease, associated with tumor stage/ It is } \\
\text { not specific for prostate cancer }\end{array}$ \\
\hline AMACR & $\begin{array}{l}\text { Peroxisomal } \\
\text { and mito- } \\
\text { chondrial } \\
\text { enzyme }\end{array}$ & $\begin{array}{l}\text { It has key role in } \\
\beta \text {-oxidation of } \\
\text { branched chain } \\
\text { fatty acids and the } \\
\text { bile acid }\end{array}$ & $\begin{array}{l}\text { Prog- } \\
\text { nosis/ Di- } \\
\text { agnosis }\end{array}$ & $\begin{array}{l}\text { Immunohistochemi- } \\
\text { cally RT-PCR West- } \\
\text { ern blot analysis in } \\
\text { urine RT-PCR in } \\
\text { prostatic secretions } \\
\text { Autoantibodies to } \\
\text { AMACR in serum }\end{array}$ & $\begin{array}{l}\text { Specific biomarker/ Use in some clinical } \\
\text { centers (microfocal cancer diagnosis on } \\
\text { biopsy specimens) }\end{array}$ \\
\hline IL-6 & Cytokine & $\begin{array}{l}\text { hematopoiesis the } \\
\text { immuneresponse, } \\
\text { theacute-phase re- } \\
\text { sponse, differentia- } \\
\text { tion of B-cells }\end{array}$ & $\begin{array}{l}\text { Progno- } \\
\text { sis }\end{array}$ & Immunoassay & $\begin{array}{l}\text { Easily measurement/ Increase in so much } \\
\text { inflammatory conditions }\end{array}$ \\
\hline TGF $\beta 1$ & Cytokine & $\begin{array}{l}\text { Many cellular } \\
\text { functions, includ- } \\
\text { ing the control of } \\
\text { cell growth, cell } \\
\text { proliferation and } \\
\text { differentiation } \\
\text { apoptosis, angio- } \\
\text { genesis }\end{array}$ & $\begin{array}{l}\text { Progno- } \\
\text { sis }\end{array}$ & Immunoassays & $\begin{array}{l}\text { High level of this cytokine associate with } \\
\text { prostate cancer/ Some studies indicated } \\
\text { any association }\end{array}$ \\
\hline IGF-1 & $\begin{array}{l}\text { A hormone } \\
\text { similar in } \\
\text { molecular } \\
\text { structure to } \\
\text { insulin }\end{array}$ & $\begin{array}{l}\text { A strong stimulator } \\
\text { of normal and neo- } \\
\text { plastic cell growth, } \\
\text { anti-apoptotic }\end{array}$ & $\begin{array}{l}\text { Prog- } \\
\text { nosis/ Di- } \\
\text { agnosis }\end{array}$ & ELISA & $\begin{array}{l}\text { Easy measurement/ Low sensitivity and } \\
\text { specificity }\end{array}$ \\
\hline PSCA & $\begin{array}{l}\text { Glycopro- } \\
\text { tein of cell } \\
\text { surface }\end{array}$ & $\begin{array}{l}\text { Cell surface } \\
\text { marker, possibly } \\
\text { proliferation of } \\
\text { stem cells signal } \\
\text { transduction }\end{array}$ & $\begin{array}{l}\text { Progno- } \\
\text { sis }\end{array}$ & RT-PCR & $\begin{array}{l}\text { Over expression in great number of pros- } \\
\text { tate cancer which is associated with higher } \\
\text { Gleason grade and more progressed tumor } \\
\text { stage, degree of metastasis }\end{array}$ \\
\hline $\begin{array}{l}\text { PSA } \\
\text { velocity } \\
\text { (PSAv) }\end{array}$ & $\begin{array}{l}\text { Sequential } \\
\text { evaluation of } \\
\text { PSA levels } \\
\text { over time }\end{array}$ & ------------ & $\begin{array}{l}\text { Progno- } \\
\text { sis }\end{array}$ & $\begin{array}{l}\text { By counting of times } \\
\text { the blood increases } \\
\text { PSA level by } 0.4 \mathrm{ng} / \\
\mathrm{mL}\end{array}$ & $\begin{array}{l}\text { High specificity/Low sensitivity and so } \\
\text { low specificity }\end{array}$ \\
\hline $\begin{array}{l}\text { Ki-67 } \\
\text { (prolif- } \\
\text { eration } \\
\text { index) }\end{array}$ & $\begin{array}{l}\text { A DNA bind- } \\
\text { ing protein }\end{array}$ & $\begin{array}{l}\text { A cellular marker } \\
\text { for proliferation, } \\
\text { involved in cell } \\
\text { proliferation }\end{array}$ & $\begin{array}{l}\text { Progno- } \\
\text { sis }\end{array}$ & RT-PCR & $\begin{array}{l}\text { Considered as one of the most important } \\
\text { prognosis biomarkers of prostate cancer /It } \\
\text { is not using on common }\end{array}$ \\
\hline P53 & $\begin{array}{l}\text { A tumor } \\
\text { suppressor } \\
\text { protein }\end{array}$ & $\begin{array}{l}\text { Regulation of } \\
\text { intrinsic or mito- } \\
\text { chondrial apopto- } \\
\text { sis pathway }\end{array}$ & $\begin{array}{l}\text { Progno- } \\
\text { sis }\end{array}$ & ELISA & $\begin{array}{l}80 \% \text { to } 90 \% \text { accuracy/The change of } \\
\text { expression in some of the cancers }\end{array}$ \\
\hline
\end{tabular}




\begin{tabular}{|l|l|l|l|l|l|}
\hline $\begin{array}{l}\text { An- } \\
\text { drogen } \\
\text { receptor }\end{array}$ & $\begin{array}{l}\text { A nuclear } \\
\text { transcription } \\
\text { factor }\end{array}$ & $\begin{array}{l}\text { Binds to the male } \\
\text { sex steroids and } \\
\text { involves in their } \\
\text { biological effects } \\
\text { in target cells } \\
\text { sis }\end{array}$ & $\begin{array}{l}\text { Progno- } \\
\text { RT-PCR }\end{array}$ & $\begin{array}{l}\text { Better understanding of the causes produc- } \\
\text { ing of liability of androgen-independent } \\
\text { growth for some aggressive tumors /Many } \\
\text { prostate cancers become hormone refrac- } \\
\text { tory, develop more and eventually lead to } \\
\text { deadly outcome, now its research only }\end{array}$ \\
\hline $\begin{array}{l}\text { E-cad- } \\
\text { herin }\end{array}$ & $\begin{array}{l}\text { A 120 KD a } \\
\text { trans mem- } \\
\text { brane glyco- } \\
\text { protein and } \\
\text { a member } \\
\text { of cadherin } \\
\text { family }\end{array}$ & $\begin{array}{l}\text { Involved in cell- } \\
\text { cell recognition } \\
\text { and adhesion }\end{array}$ & $\begin{array}{l}\text { Progno- } \\
\text { sis and } \\
\text { aggres- } \\
\text { sive } \\
\text { transfor- } \\
\text { mation }\end{array}$ & Immunoassays & $\begin{array}{l}\text { Immunohistochemy and molecular genetic } \\
\text { studies indicate its potential important rela- } \\
\text { tionship in prostate cancer/ Research only }\end{array}$ \\
\hline VEGF & $\begin{array}{l}\text { A signal } \\
\text { protein } \\
\text { produced } \\
\text { by cells that } \\
\text { stimulates } \\
\text { vasculo- } \\
\text { genesis and } \\
\text { angiogenesis }\end{array}$ & $\begin{array}{l}\text { It is part of the } \\
\text { system that } \\
\text { restores the } \\
\text { oxygen supply } \\
\text { to tissues when } \\
\text { blood circulation } \\
\text { is inadequate. }\end{array}$ & $\begin{array}{l}\text { Progno- } \\
\text { sis }\end{array}$ & ELISA & \\
\hline
\end{tabular}

Table 2. Age-specific Range for PSA(Zorn KC, 2014)

\begin{tabular}{lccc}
\hline \multicolumn{4}{c}{ Age-Specific Reference Ranges for Serum PSA (ng/ml) } \\
\hline Age Range (Years) & $\begin{array}{c}\text { Asian } \\
\text { Americans }\end{array}$ & $\begin{array}{c}\text { African } \\
\text { Americans }\end{array}$ & Caucasians \\
\hline $40-49$ & $0-2.0$ & $0-2.0$ & $0-2.5$ \\
$50-59$ & $0-3.0$ & $0-4.0$ & $0-3.5$ \\
$60-69$ & $0-4.0$ & $0-4.5$ & $0-4.5$ \\
$70-79$ & $0-5.0$ & $0-5.5$ & $0-6.5$ \\
\hline
\end{tabular}

Table 3. The Association of Free/Total PSA Ratio in Men with PSA Levels of 2.1-10.0 ng/ml and Probability of Prostate Cancer (Kitagawa et al., 2014)

\begin{tabular}{cc}
\hline Free/total PSA & $\begin{array}{c}\text { Probability of } \\
\text { Prostate cancer (\%) }\end{array}$ \\
\hline$\leq 0.08$ & 64.5 \\
$0.09-0.13$ & 41.2 \\
$0.14-0.22$ & 28.5 \\
$\geq 0.23$ & 14.3 \\
\hline
\end{tabular}

aggressive prostate cancer and metastasis risk(Mohammed, 2014). Cell cycle progression, cell adhesion and migration, motility of tumor cells also immune system modulation, androgen signaling are biological processes that depicted in GC (Erho et al., 2013).

By using long term follow up (median 16.9 year) GC was assessed for clinical adverse outcome and presented enhanced risk stratification among patients after radical prostatectomy (Erho et al., 2013). Other studies confirmed these results (Karnes et al., 2013), especially combination of GC with routine risk assessment markers make possible better recognition of high risk patients after radical prostatectomy (Ross et al., 2003).

\section{Cell cycle progression (CCP) gene and Polaris}

Cell cycle progression (CCP) genes can be estimate by Polaris prostate cancer testthat has been confirmed in several cohorts, this test can evaluate aggressiveness of prostate cancer (Bishoff et al., 2014; Crawford et al., 2014). The CCP score is introduced as a strong predictor of prostate cancer outcome, probability of relapse or progression after prostatectomy during 10 years follow up particularly when combined with clinical variables. The researchers believed that with additional studies, CCP score may have a fundamental role in determination of appropriate treatment in prostate cancer patients (Cuzick et al., 2011; Cuzick et al., 2012).

\section{Genomic prostate score (GPS) and Oncotype DX}

The Oncotype DX prostate cancer is a type of test that analysis the expression level of 17 genes associated with prostate cancer aggressiveness, clinical recurrence, adverse pathology, prostate cancer death. The results of test are informed as a Genomic Prostate Score (GPS) that varies from 0 to 100 . The recently studies indicated that GPS can change risk stratification and predict high grade or high stage of prostate cancer at diagnosis.GPS can help to determine the appropriate treatment, surveillance or therapy, in men with newly diagnosed low risk prostate cancer (Klein et al., 2014).

\section{References}

Achyut BR, Yang L (2011). Transforming growth factor- $\beta$ in the gastrointestinal and hepatic tumor microenvironment. Gastroenterology, 141, 1167-78.

Al-Maghrebi M, Kehinde EO, Anim JT, et al (2012). The role of combined measurement of tissue mRNA levels of AMACR and survivin in the diagnosis and risk stratification of patients with suspected prostate cancer. Intern Urol Nephrol, 44, 1681-9.

Askari F, Parizi MK, Jessri M, et al (2014). Fruit and vegetable intake in relation to prostate cancer in Iranian men: a casecontrol study. Asian Pac J Cancer Prev, 15, 5223-7.

Bassler TJ Jr, Orozco R, Bassler IC, O’Dowd GJ, Stamey TA (1998). Most prostate cancers missed by raising the upper limit of normal prostate-specific antigen for men in their sixties are clinically significant. Urology, 52, 1064-9.

Bedolla R, Prihoda TJ, Kreisberg JI, et al (2007). Determining risk of biochemical recurrence in prostate cancer by immunohistochemical detection of PTEN expression and Akt activation. Clin Cancer Res, 13, 3860-7.

Behnsawy HM, Miyake H, Harada K-I, et al (2013). Expression 
patterns of epithelial-mesenchymal transition markers in localized prostate cancer: significance in clinicopathological outcomes following radical prostatectomy. BJU Intern, 111, 30-7.

Bensalah K, Lotan Y, Karam JA, et al (2007). New circulating biomarkers for prostate cancer. Prostate Cancer, 11, 112-20.

Berruti A, Dogliotti L, Mosca A, et al (2001). Potential clinical value of circulating chromogranin A in patients with prostate carcinoma. Ann Oncol, 12, 153-S7.

Bickers B, Aukim-Hastie C (2009). New molecular biomarkers for the prognosis and management of prostate cancer the post PSA era. Anticancer Res, 29, 3289-98.

Bishoff JT, Freedland SJ, Gerber L, et al (2014). Prognostic utility of the cell cycle progression score generated from biopsy in men treated with prostatectomy. J Urol, 192, 409-14.

Bocan EV, Mederle O, Sarb S, et al (2011). Correlation between histopathological form and the degree of neuroendocrine differentiations in prostate cancer. Rom J Morphol Embryol, 52, 1215-8.

Bostwick DG, Burke HB, Djakiew D, et al (2004). Human prostate cancer risk factors. Cancer, 101, 2371-490.

Buhmeida A, Pyrhonen S, Laato M, Collan Y (2006). Prognostic factors in prostate cancer. Diagnostic Pathol, 1, 1-15.

Carter HB, Kettermann A, Ferrucci L, Landis P, Metter EJ (2007). Prostate-specific antigen velocity risk count assessment: a new concept for detection of life-threatening prostate cancer during window of curability. Urology, 70, 685-90.

Cary KC, Cooperberg MR (2013). Biomarkers in prostate cancer surveillance and screening: past, present, and future. Therapeutic Advances Urol, 5, 318-29.

Catalona WJ, Partin AW, Slawin KM, et al (1998). Use of the percentage of free prostate-specific antigen to enhance differentiation of prostate cancer from benign prostatic disease: a prospective multicenter clinical trial. JAMA, 279, 1542-7.

Chan JM, Stampfer MJ, Ma J, et al (2002). Insulin-like growth factor-I (IGF-I) and IGF binding protein-3 as predictors of advanced-stage prostate cancer. J Nat Cancer Inst, $\mathbf{9 4 ,}$ 1099-106.

Charrier J-P, Tournel C, Michel S, et al (2001). Differential diagnosis of prostate cancer and benign prostate hyperplasia using two-dimensional electrophoresis. Electrophoresis, 22, 1861-6.

Chaux A, Peskoe SB, Gonzalez-Roibon N, et al (2012). Loss of PTEN expression is associated with increased risk of recurrence after prostatectomy for clinically localized prostate cancer. Modern Pathol, 25, 1543-9.

Chunthapong J, Seftor EA, Khalkhali-Ellis Z, et al (2004). Dual roles of E-cadherin in prostate cancer invasion. $J$ Cellular Biochem, 91, 649-61.

Crawford ED, Scholz MC, Kar AJ, et al (2014). Cell cycle progression score and treatment decisions in prostate cancer: results from an ongoing registry. Curr Med Res Opin, 30, 1025-31.

Culig Z, Steiner H, Bartsch G, et al (2005). Interleukin-6 regulation of prostate cancer cell growth. J Cellular Biochem, 95, 497-505.

Cuzick J, Berney DM, Fisher G, et al (2012). Prognostic value of a cell cycle progression signature for prostate cancer death in a conservatively managed needle biopsy cohort. British J Cancer, 106, 1095-9.

Cuzick J, Swanson GP, Fisher G, et al (2011). Prognostic value of an RNA expression signature derived from cell cycle proliferation genes in patients with prostate cancer: a retrospective study. Lancet Oncol, 12, 245-55.
D'Amico AV, Chen M-H, Roehl KA, et al (2004). Preoperative PSA velocity and the risk of death from prostate cancer after radical prostatectomy. New England J Med, 351, 125-35.

Deng Q-W, He B-S, Pan Y-Q, et al (2014). Roles of E-cadherin (CDH1) genetic variations in cancer risk: a meta-analysis. Asian Pac J Cancer Prev, 15, 3705-13.

Di JM, Zhou J, Zhou XL, et al (2009). Cyclooxygenase-2 expression is associated with vascular endothelial growth factor-C and lymph node metastases in human prostate cancer. Arch Med Res, 40, 268-75.

Djavan B, Waldert M, Seitz C, et al (2001). Insulin-like growth factors and prostate cancer. World J Urol, 19, 225-33.

Donovan MJ, Hamann S, Clayton M, et al (2008). Systems pathology approach for the prediction of prostate cancer progression after radical prostatectomy. J Clin Oncol, 26, 3923-9.

Doolan G, Benke G, Giles G (2014). An update on occupation and prostate cancer. Asian Pac J Cancer Prev, 15, 501-16.

Eiró N, Bermudez-Fernandez S, Fernandez-Garcia B, et al (2014). Analysis of the expression of interleukins, interferon $\beta$, and nuclear factor- $\varkappa \mathrm{B}$ in prostate cancer and their relationship with biochemical recurrence. J Immun, 37, 366-73.

Erho N, Crisan A, Vergara IA, et al (2013). Discovery and validation of a prostate cancer genomic classifier that predicts early metastasis following radical prostatectomy. PloS One, 8, 66855.

Erkal EY, Bora H, Tepeoglu M, et al (2014). Role of vascular endothelial growth factor in clinically localized prostate cancer treated with radiation therapy. Balkan Med J,31,43-9.

Etzioni R, Penson DF, Legler JM, et al (2002). Overdiagnosis due to prostate-specific antigen screening: lessons from U.S. prostate cancer incidence trends. J Nat Cancer Inst, 94, 981-90.

Euling SY, Kimmel CA (2001). Developmental stage sensitivity and mode of action information for androgen agonists and antagonists. Science Total Environ, 274, 103-13.

Fang J, Ding M, Yang L, et al (2007). PI3K/PTEN/AKT signaling regulates prostate tumor angiogenesis. Cellular Signal, 19, 2487-97.

Ferdinandusse S, Denis S, Ijlst L, et al (2000). Subcellular localization and physiological role of $\alpha$-methylacyl-CoA racemase. J Lipid Res, 41, 1890-6.

Finne P, Auvinen A, Maattänen L, et al (2008). Diagnostic value of free prostate-specific antigen among men with a prostate-specific antigen level of $<3.0 \mu g$ per liter. Eur Urol, 54, 241-482.

Freedland SJ, deGregorio F, Sacoolidge JC, et al (2003). Preoperative p27 status is an independent predictor of prostate specific antigen failure following radical prostatectomy. J Urol, 169, 1325-30.

Garg M, Dalela D, Goel A, et al (2014). Prevention of prostate cancer with vitamins-current perspectives. Asian Pac J Cancer Prev, 15, 1897-904.

George DJ, Halabi S, Shepard TF, et al (2005). The prognostic significance of plasma interleukin-6 levels in patients with metastatic hormone-refractory prostate cancer: results from cancer and leukemia group B 9480. Clin Cancer Res, 11, 1815-20.

Globocan (2012). Prostate cancer: estimated incidence, mortality and prevalence worldwide in 2012 [Online]. Available: http://globocan.iarc.fr/Pages/fact_sheets_cancer.aspx.

Graefen M, Karakiewicz PI, Cagiannos I, et al (2002). Percent free prostate specific antigen is not an independent predictor of organ confinement or prostate specific antigen recurrence in unscreened patients with localized prostate cancer treated with radical prostatectomy. $J$ Urol, 167, 1306-9. 
Gravdal K, Halvorsen OJ, Haukaas SA, Akslen LA (2007). A switch from E-cadherin to $\mathrm{N}$-cadherin expression indicates epithelial to mesenchymal transition and is of strong and independent importance for the progress of prostate cancer. Clin Cancer Res, 13, 7003-11.

Grignon DJ, Caplan R, Sarkar FH, et al (1997). p53 status and prognosis of locally advanced prostatic adenocarcinoma: a study based on RTOG 8610. J Natl Cancer Inst, 89, 158-65.

Halvorsen OJ (2008). Molecular and prognostic markers in prostate cancer. A study of cell-cycle regulators, angiogenesis and candidate markers. APMIS Suppl, 5-62.

Han K-R, Seligson DB, Liu X, et al (2004). Prostate stem cell antigen expression is associated with gleason score, seminal vesicle invasion and capsular invasion in prostate cancer. $J$ Urol, 171, 1117-21.

Hara N, Kasahara T, Kawasaki T, et al (2002). Reverse transcription-polymerase chain reaction detection of prostate-specific antigen, prostate-specific membrane antigen, and prostate stem cell antigen in one milliliter of peripheral blood value for the staging of prostate cancer. Clin Cancer Res, 8, 1794-9.

Hicklin DJ, Ellis LM (2005). Role of the vascular endothelial growth factor pathway in tumor growth and angiogenesis. J Clin Oncol, 23, 1011-27.

Howlader N, Noone AM, Krapcho M, et al (2011). SEER cancer statistics review, 1975-2008, national cancer institute. Bethesda, MD, http://seer.cancer.gov/csr/1975_2008/,based on November 2010 SEER data submission, posted to the SEER web site.

Ilyin SE, Belkowski SM, Plata-Salaman CR (2004). Biomarker discovery and validation: technologies and integrative approaches. Trends Biotechnol, 22, 411-6.

Isshiki S, Akakura K, Komiya A, et al (2002). Chromogranin a concentration as a serum marker to predict prognosis after endocrine therapy for prostate cancer. J Urol, 167, 512-5.

Ito K (2014). Prostate cancer in Asian men. Nat Rev Urol, 11, 197-212.

Jaggi M, Nazemi T, Abrahams NA, et al (2006). N-cadherin switching occurs in high Gleason grade prostate cancer. Prostate, 66, 193-9.

Jiang Z, Wu CL, Woda BA, et al (2004). Alpha-methylacyl-CoA racemase: a multi-institutional study of a new prostate cancer marker. Histopathol, 45, 218-25.

Jung K, Brux B, Lein M, et al (2000). Molecular forms of prostate-specific antigen in malignant and benign prostatic tissue: biochemical and diagnostic implications. Clin Chem, 46, 47-54.

Karnes RJ, Bergstralh EJ, Davicioni E, et al (2013). Validation of a genomic classifier that predicts metastasis following radical prostatectomy in an at risk patient population. $J$ Urol, 190, 2047-53.

Kattan MW, Shariat SF, Andrews B, et al (2003). The addition of interleukin- 6 soluble receptor and transforming growth factor beta 1 improves a preoperative nomogram for predicting biochemical progression in patients with clinically localized prostate cancer. J Clin Oncol, 21, 3573-9.

Khan MO, Ather MH (2011). Chromogranin a serum marker for prostate cancer. JPMA, 61, 108-11.

Kim H-S, Ingermann AR, Tsubaki J, et al (2004). Insulin-like growth factor-binding protein 3 induces caspase-dependent apoptosis through a death receptor-mediated pathway in MCF-7 human breast cancer cells. Cancer Res, 64, 2229-37.

Kitagawa Y, Ueno S, Izumi K, et al (2014). Cumulative probability of prostate cancer detection in biopsy according to free/total PSA ratio in men with total PSA levels of $2.1-10.0 \mathrm{ng} / \mathrm{ml}$ at population screening. J Cancer Res Clin Oncol, 140, 53-9.
DOI:http://dx.doi.org/10.7314/APJCP.2015.16.7.2601 Biomarkers for Evaluation of Prostate Cancer Prognosis

Klein EA, Cooperberg MR, Magi-Galluzzi C, et al (2014). A 17gene assay to predict prostate cancer aggressiveness in the context of gleason grade heterogeneity, tumor multifocality, and biopsy undersampling. European Urol, 66, 550-60.

Koksal IT, Dirice E, Yasar D, et al (2004). The assessment of PTEN tumor suppressor gene in combination with Gleason scoring and serum PSA to evaluate progression of prostate carcinoma. Urol Oncol, 22, 307-12.

Kollermann J HB (2001). Expression of vascular endothelial growth factor (VEGF) and VEGF receptor Flk-1 in benign, premalignant, and malignant prostate tissue. Am J ClinPathol, 116, 115-21.

Kuczyk MA, Bokemeyer C, Hartmann J, et al (2001). Predictive value of altered $\mathrm{p} 27 \mathrm{Kip} 1$ and $\mathrm{p} 21 \mathrm{WAF} / \mathrm{Cip} 1$ protein expression for the clinical prognosis of patients with localized prostate cancer. Oncol Reports, 8, 1401-7.

Kuniyasu H, Troncoso P, Johnston D, et al (2000). Relative expression of type IV collagenase, E-cadherin, and vascular endothelial growth factor/vascular permeability factor in prostatectomy specimens distinguishes organ-confined from pathologically advanced prostate cancers. Clin Cancer Res, 6, 2295-308.

Laitinen S, Martikainen PM, Tolonen T, et al (2008). EZH2, $\mathrm{Ki}-67$ and MCM7 are prognostic markers in prostatectomy treated patients. Intern J Cancer, 122, 595-602.

Larkin SET, Holmes S, Cree IA, et al (2012). Identification of markers of prostate cancer progression using candidate gene expression. Br J Cancer, 106, 157-65.

Lawrence TS (2011). Cancer: Principles and Practice of Oncology. in eds Philadelphia, Pa: Lippincott Williams \& Wilkins, 2011, 1220-71.

Li R, Heydon K, Hammond ME, et al (2004a). Ki-67 staining index predicts distant metastasis and survival in locally advanced prostate cancer treated with radiotherapy an analysis of patients in radiation therapy oncology group protocol 86-10. Clin Cancer Res, 10, 4118-24.

Li R, Younes M, Wheeler TM, et al (2004b). Expression of vascular endothelial growth factor receptor-3 (VEGFR-3) in human prostate. Prostate, 58, 193-9.

Li Y, Su J, DingZhang X, et al (2011). PTEN deletion and heme oxygenase-1 overexpression cooperate in prostate cancer progression and are associated with adverse clinical outcome. J Pathol, 224, 90-100.

Lin DW (2009). Beyond PSA: utility of novel tumor markers in the setting of elevated PSA. Urol Oncol, 27, 315-21.

Loeb S, Metter EJ, Kan D, Roehl KA, Catalona WJ (2012). Prostate-specific antigen velocity risk count improves the specificity of screening for clinically significant prostate cancer. BJU Int, 109, 508-13

Lopergolo A, Zaffaroni N (2009). Biomolecular markers of outcome prediction in prostate cancer. Cancer, 115, 3058-67.

Lotan TL, Gurel B, Sutcliffe S, et al (2011). PTEN protein loss by immunostaining: analytic validation and prognostic indicator for a high risk surgical cohort of prostate cancer patients. Clin Cancer Res, 17, 6563-73.

Madu Co LY (2010). Novel diagnostic biomarkers for prostate cancer. J Cancer, 1, 150-77.

Aghaei M, Panjehpour M, Karami-Tehrani F, Salami S (2011). Molecular mechanisms of A3 adenosine receptor-induced G1 cell cycle arrest and apoptosis in androgen-dependent and independent prostate cancer cell lines: involvement of intrinsic pathway. J Cancer Res Clin Oncol, 137, 1511-23.

Marika J. Linja, Savinainen KJ, Saramaki OR, et al (2001). Amplification and overexpression of androgen receptor gene in hormone-refractory prostate cancer. Cancer Res, 61 .

Mehta HH, Gao Q, Galet C, et al (2011). IGFBP-3 is a metastasis suppression gene in prostate cancer. Cancer Res, 71, 5154- 
63.

Michalaki V, Syrigos K, Charles P, et al (2004). Serum levels of IL-6 and TNF- $\alpha$ correlate with clinicopathological features and patient survival in patients with prostate cancer. British J Cancer, 90, 2312-6.

Mohammed AA (2014). Biomarkers in prostate cancer: new era and prospective. Med Oncol, 31, 140.

Mulholland DJ, Tran LM, Li Y, et al (2011). Cell autonomous role of PTEN in regulating castration-resistant prostate cancer growth. Cancer Cell, 19, 792-804.

Nakashima J, Tachibana M, Horiguchi Y, et al (2000). Serum interleukin 6 as a prognostic factor in patients with prostate cancer. Clin Cancer Res, 6, 2702-6.

Nixon RG, Wener MH, Smith KM, et al (1997). Biological variation of prostate specific antigen levels in serum: an evaluation of day-to-day physiological fluctuations in a well-defined cohort of 24 patients. J Urol, 157, 2183-90.

Oxley JD, Winkler MH, Parry K, et al (2002). p53 and bcl-2 immunohistochemistry in preoperative biopsies as predictors of biochemical recurrence after radical prostatectomy. BJU Int, 89, 27-32.

Panjehpour M, Movahedian A, Sadeghi H, et al (2012). Adenosine receptor expression in two different human cancer cell lines at molecular level. Iranian J Cancer Prev, 3, 111-6.

Patel DA, Presti JC, McNeal JE, et al (2005). Preoperative PSA velocity is an independent prognostic factor for relapse after radical prostatectomy. J Clin Oncol, 23, 6157-62.

Perry KT, Anthony CT, Case T, et al (1997). Transforming growth factor beta as a clinical biomarker for prostate cancer. Urology, 49, 151-5.

Pollack A, DeSilvio M, Khor LY, et al (2004). Ki-67 staining is a strong predictor of distant metastasis and mortality for men with prostate cancer treated with radiotherapy plus androgen deprivation: radiation therapy oncology group trial 92-02.J Clin Oncol, 22, 2133-40.

Quinn Di HsSMSRL (2005). Molecular markers of prostate cancer outcome. Eur J Cancer, 41, 858-87.

Ramírez ML, Nelson EC, Evans CP (2008). Beyond prostatespecific antigen: alternate serum markers. Prostate Cancer , 11, 216-29.

Reiter RE, Gu Z, Watabe T, et al (1998). Prostate stem cell antigen: A cell surface marker overexpressed in prostate cancer. Proceed Nat Acad Sci, 95, 1735-40.

Reiter RE, Sato I, Thomas G, et al (2000). Coamplification of prostate stem cell antigen (PSCA) and MYC in locally advanced prostate cancer. Genes, Chromosomes Cancer, 27, 95-103.

Riegman PHJ, Vlietstra RJ, Klaassen P, et al (1989). The prostate-specific antigen gene and the human glandular kallikrein-1 gene are tandemly located on chromosome 19. FEBS Letters, 247, 123-6.

Rigaud J, Tiguert R, Decobert M, et al (2004). Expression of p21 cell cycle protein is an independent predictor of response to salvage radiotherapy after radical prostatectomy. Prostate, 58, 269-76.

Rittenhouse HG, Finlay JA, Mikolajczyk SD, et al (1998). human kallikrein 2 (hK2) and prostate-specific antigen (PSA): two closely related, but distinct, kallikreins in the prostate. $\mathrm{Crc}$ Cr Rev Cl Lab Sc, 35, 275-368.

Rodriguez-Berriguete G, Sanchez-Espiridion B, Cansino JR, et al (2013). Clinical significance of both tumor and stromal expression of components of the IL- 1 and TNF- $\alpha$ signaling pathways in prostate cancer. Cytokine, 64, 555-63.

Rosner IL, Ravindranath L, Furusato B, et al (2007). Higher tumor to benign ratio of the androgen receptor mRNA expression associates with prostate cancer progression after radical prostatectomy. Urology, 70, 1225-9.
Ross JS, Jennings TA, Nazeer T, et al (2003). Prognostic factors in prostate cancer. Am J Clin Pathol, 120, 85-100.

Rubin MA, Mucci NR, Figurski J, et al (2001). E-cadherin expression in prostate cancer: A broad survey using highdensity tissue microarray technology. Human Pathol, 32, 690-7.

Rubio J, Ramos D, Lopez-Guerrero JA, et al (2005). Immunohistochemical expression of Ki-67 antigen, Cox2 and $\mathrm{Bax} / \mathrm{Bcl}-2$ in prostate cancer; prognostic value in biopsies and radical prostatectomy specimens. European Urol, 48, 745-51.

Safarinejad MR, Shafiei N, Safarinejad S (2011). Relationship of insulin-like growth factor (IGF) binding protein-3 (IGFBP-3) gene polymorphism with the susceptibility to development of prostate cancer and influence on serum levels of IGF-I, and IGFBP-3. Growth Horm IGF Res, 21, 146-54.

Sardana G, Dowell B, Diamandis EP (2008). Emerging biomarkers for the diagnosis and prognosis of prostate cancer. Clin Chem, 54, 1951-60.

Schwarze SR, DePrimo SE, Grabert LM, et al (2002). Novel pathways associated with bypassing cellular senescence in human prostate epithelial cells. J Biol Chem, 277, 14877-83.

Shariat SF, Canto EI, Kattan MW, Slawin KM (2004). Beyond prostate-specific antigen: new serologic biomarkers for improved diagnosis and management of prostate cancer. Rev Urol, 6, 58-72.

Shariat SF, Abdel-Aziz KF, Roehrborn CG, et al (2006). Preoperative percent free PSA predicts clinical outcomes in patients treated with radical prostatectomy with total PSA levels below $10 \mathrm{ng} / \mathrm{ml}$. European Urol, 49, 293-302.

Shariat SF, Andrews B, Kattan MW, et al (2001). Plasma levels of interleukin-6 and its soluble receptor are associated with prostate cancer progression and metastasis. Urology, 58, 1008-15.

Shariat SF, Karam JA, Margulis V, et al (2008a). New bloodbased biomarkers for the diagnosis, staging and prognosis of prostate cancer. BJU Intern, 101, 675-83.

Shariat SF, Kattan MW, Traxel E, et al (2004a). Association of Pre- and postoperative plasma levels of transforming growth factor $\beta 1$ and interleukin 6 and its soluble receptor with prostate cancer progression. Clin Cancer Res, 10, 1992-9.

Shariat SF, Lamb DJ, Kattan MW, et al (2002). Association of preoperative plasma levels of insulin-like growth factor $\mathrm{i}$ and insulin-like growth factor binding proteins-2 and -3 with prostate cancer invasion, progression, and metastasis. $J$ Clin Oncol, 20, 833-41.

Shariat SF, Menesses-Diaz A, Kim IY, et al (2004b). Tissue expression of transforming growth factor- $\beta 1$ and its receptors: correlation with pathologic features and biochemical progression in patients undergoing radical prostatectomy. Urology, 63, 1191-7.

Shariat SF, Walz J, Roehrborn CG, et al (2008b). Early postoperative plasma transforming growth factor- $\beta 1$ is a strong predictor of biochemical progression after radical prostatectomy. J Urol, 179, 1593-7.

Siddiqui E, Mumtaz FH, Gelister J (2004). Understanding prostate cancer. J Royal Soc Promot Health, 124, 219-21.

Society AC (2013). Can prostate cancer be found early? [Online]. Available: http://www.cancer.org/cancer/prostatecancer/ detailedguide/prostate-cancer-detection.

Southwick PC, Catalona WJ, Partin AW, et al (1999). Prediction of post-radical prostatectomy pathological outcome for stage $\mathrm{T} 1 \mathrm{c}$ prostate cancer with percent free prostate specific antigen: a prospective multicenter clinical trial. J Urol, 162, 1346-51.

Sreekumar A, Laxman B, Rhodes DR, et al (2004). Humoral immune response to $\alpha$-Methylacyl-CoA racemase and 
prostate cancer. J Nat Cancer Inst, 96, 834-43.

Stamey TA, Johnstone IM, McNeal JE, et al (2002). Preoperative serum prostate specific antigen levels between 2 and $22 \mathrm{ng}$./ $\mathrm{ml}$. correlate poorly with post-radical prostatectomy cancer morphology: prostate specific antigen cure rates appear constant between 2 and $9 \mathrm{ng} . / \mathrm{ml} . J$ Urol, 167, 103-11.

Thompson IM, Ankerst D, Chi C, et al (2005). OPerating characteristics of prostate-specific antigen in men with an initial psa level of $3.0 \mathrm{ng} / \mathrm{ml}$ or lower. JAMA, 294, 66-70.

Timothy J Wilt, Ahmed HU (2013). Prostate cancer screening and the management of clinically localized disease. $B M J$, 346, 325 .

Tricoli JV, Schoenfeldt M, Conley BA (2004). Detection of prostate cancer and predicting progression current and future diagnostic markers. Clin Cancer Res, 10, 3943-53.

UK CR. (2012). Prostate cancer mortality statistics [Online]. Available: http://www.cancerresearchuk.org/cancer-info/ cancerstats/types/prostate/mortality/.

Van Veldhoven PP, Croes K, Casteels M, et al (1997). 2-methylacyl racemase: a coupled assay based on the use of pristanoyl-CoA oxidase/peroxidase and reinvestigation of its subcellular distribution in rat and human liver. Biochim Biophys Acta, 1347, 62-8.

Vergis R, Corbishley CM, Norman AR, et al (2008). Intrinsic markers of tumour hypoxia and angiogenesis in localised prostate cancer and outcome of radical treatment: a retrospective analysis of two randomised radiotherapy trials and one surgical cohort study. Lancet Oncol, 9, 342-51.

Wikström P, Damber J-E, Bergh A (2001). Role of transforming growth factor- $\beta 1$ in prostate cancer. Microsc Res Techniq, 52, 411-9.

Wolff JM, Fandel TH, Borchers H, et al (1999). Serum concentrations of transforming growth factor-beta 1 in patients with benign and malignant prostatic diseases. Anticancer Res, 19, 2657-9.

Yang J, Wu HF, Qian LX, et al (2006). Increased expressions of vascular endothelial growth factor (VEGF), VEGF-C and VEGF receptor-3 in prostate cancer tissue are associated with tumor progression. Asian J Androl, 8, 169-75.

Yoshimoto M, Cunha IW, Coudry RA, et al (2007). FISH analysis of 107 prostate cancers shows that PTEN genomic deletion is associated with poor clinical outcome. British J Cancer, 97, 678-85

Yu H, Nicar MR, Shi R, et al (2001). Levels of insulin-like growth factor I (IGF-I) and IGF binding proteins 2 and 3 in serial postoperative serum samples and risk of prostate cancer recurrence. Urology, 57, 471-5.

Yuan JJ, Coplen DE, Petros JA, et al (1992). Effects of rectal examination, prostatic massage, ultrasonography and needle biopsy on serum prostate specific antigen levels. J Urol, 147, 810-4.

Zhigang Z, Wenlv S (2004). Prostate stem cell antigen (PSCA) expression in human prostate cancer tissues: implications for prostate carcinogenesis and progression of prostate cancer. Japanese J Clin Oncol, 34, 414-9.

Zorn KC HP (2014). Prostate specific antigen [Online]. Available: http://www.medicinenet.com/prostate_specific_ antigen/page $3 . h t m$. 